\title{
Profile of Color Vision Defects in a Tertiary Care Hospital in Western Nepal
}

\author{
Godar ST, ${ }^{1 *}$ Kaini KR, ${ }^{1}$ Khattri $\mathrm{JB}^{2}$ \\ ${ }^{1}$ Department of Ophthalmology, ${ }^{2}$ Department of Psychiatry, ManipalCollege of Medical Sciences, Pokhara, Nepal
}

*Corresponding Author:

Dr. SrijanaThapa Godar, MBBS, MS

ManipalCollege of Medical Sciences,

Pokhara, Nepal

E mail: drsrijanathapa@yahoo.com

\section{Citation}

Godar ST, Kaini KR, Khattri JB. Profile of Color Vision Defects in a Tertiary Care Hospital in Western Nepal. Nepal Journal of Medical Sciences 2014;3(1):1-4.

\begin{abstract}
Background: Significant numbers of people suffer from color vision defect but most of the time remains an unnoticed problem. The present work was undertaken to study the profile of color vision defects in Western region of Nepal.
\end{abstract}

Methods: This is a cross-sectional, hospital based study conducted in a tertiary care hospital of Western Nepal from January 2012 to December 2012. Total of 971 patients were selected by simple random method. In each patient assessment of visual acuity and the examination of anterior segment and posterior segment was done. Color vision was tested by Ishihara Pseudo isochromatic chart.

Results: Out of total 971 patients, 501 were males (51.59\%) and 470 were females $(48.40 \%)$. Out of this total, $91(9.37 \%)$ had color vision defects. Among the color vision defects patients, 68 were males $(74.72 \%)$ and 23 were females $(25.27 \%)$. Congenital color vision defect was seen in $10.97 \%$ of males and $2.97 \%$ of females whereas acquired color vision defect was observed in $2.57 \%$ of males and $1.91 \%$ of females respectively. Color vision defects were observed more in Chhetri (14.38\%), followed by Brahmin (10.16\%) and Magar caste $(9.89 \%)$.

Conclusion: The prevalence of color vision defect in Nepal is significant. All people should be screened for color vision defect and advised about it so that they can take special care in daily practice as well as in future life

Keywords: Color vision defect; congenital; ishihara chart

\section{Background:}

Sir John Dalton was the first scientist to give a clear description of his own color blindness in 1794. His publication subsequently stimulated much research into the pathophysiology and genetics of the condition. ${ }^{1}$ Color vision is the ability to discriminate a light stimulus as a function of its wavelength. The sense of color is the end result of the absorption of several light stimuli from the three different types of cones and the following process and transmission of the sensory signal to the occipital cortex via the optic tract. ${ }^{2-4}$ Congenital color vision defect (CVD) has a prevalence of $8 \%$ for men and $0.4 \%$ for women in general population. ${ }^{5}$ The acquired deficiencies are caused by ocular and intracranial pathologies, ${ }^{5}$ many drugs, ${ }^{6}$ diabetic retinopathy, hypertension, 
glaucoma, macular degeneration, yellowing of the lens ${ }^{7}$ due to ageing.Congenital color vision deficiencies are stationary and usually affect both eyes equally, whereas acquired deficiencies may be progressive and may affect just one eye depending on the underlying cause.Red- green perceptive disorders are $\mathrm{x}$ - linked recessive ${ }^{8}$ and thus common in males but is transmitted via female.

Various professions require normal color vision.Anyone who is color blind should be advised against training for occupations like pilots, certain jobs in armed forces, electrical jobs, navigators and police. ${ }^{9}$ Histopathologist and medical scientific officers can be at a considerable disadvantage in work if they have impaired color vision. ${ }^{10}$

There is paucity of studies on this topic from Western region of Nepal. Only one study was conducted focusing only in the school children's in Western Nepal. This study aims to identify the profile of color vision deficiency in Manipal Teaching Hospital, a tertiary care center in WesternNepal.

\section{Methods:}

This is a cross-sectional, hospital based study conducted in a tertiary care hospital of Western Nepal from January 2012 to December 2012. Total number of patients in one year duration in Ophthalmology OPD was 11921. 971 patients were selected by simple random method. An informed consent was taken from patients or their parents in cases of children.

Each patient was examined thoroughly including assessment of visual acuity with the help of internally illuminated Snellen's visual acuity chart. Anterior segment was evaluated with the help of slit lamp. The posterior segment was evaluated with the help of direct ophthalmoscope and or slit lamp biomicroscopy with +90.D lens.

Color vision was tested by using Ishihara Pseudoisochromatic Chart ("Ishihara Type Tests for color blindness" - 38 plates (1990) Eye Care - Ludhiana, India). Subjects were asked to seat in a room with natural day light and asked to read the chart keeping it $33 \mathrm{~cm}$ away from the eyes. The type of color vision deficiency was differentiated with the help of key provided with the chart. Two or more mistakes were taken as evidence of defective color vision.

Data of each case was entered in a specially designed proforma and the whole data was analyzed using a SPSS program.

\section{Results:}

Total number of patients were 971, out of which 501 were males $(51.59 \%)$ and 470 were females $(48.40 \%)$. 91 subjects $(9.37 \%)$ were found to be suffering from color vision defects. Among this 91 subjects, 68 were males $(74.72 \%)$ and 23 were females $(25.27 \%)$. Congenital color vision defect was seen in $10.97 \%$ of males and $2.97 \%$ of females whereas acquired color vision defect was observed in $2.57 \%$ of males and $1.91 \%$ of females respectively (Table 1 ).

Table 1: Distribution of gender according to the type of color vision defects $(\mathrm{n}=971)$

\begin{tabular}{lcccc}
\hline \multicolumn{1}{c}{ Type } & Gender & $\begin{array}{c}\text { Total } \\
\text { screened }\end{array}$ & $\begin{array}{c}\text { Number } \\
\text { affected }\end{array}$ & Percentage \\
\hline $\begin{array}{l}\text { Congenital } \\
\text { color vision } \\
\text { defect }\end{array}$ & Male & 501 & 55 & 10.97 \\
$\begin{array}{l}\text { Acquired } \\
\text { color vision } \\
\text { defect }\end{array}$ & Memale & 470 & 14 & 2.97 \\
\hline
\end{tabular}

Table 2 shows that majority of the patients of color vision defects were in the second (31.86\%) and third $(23.07 \%)$ decade of life and table 3 shows that color vision defect was observed more in Chhetri (14.38\%) followed by Brahmin $(10.16 \%)$ and Magar caste $(9.89 \%)$.

Table 2: Age range of patients with color vision defects $(\mathrm{n}=91)$

\begin{tabular}{lcc}
\hline Age (in years) & Number & Percentage \\
\hline $\mathbf{1 - 1 0}$ & 5 & 5.49 \\
$\mathbf{1 1 - 2 0}$ & 29 & 31.86 \\
$\mathbf{2 1 - 3 0}$ & 21 & 23.07 \\
$\mathbf{3 1 - 4 0}$ & 18 & 19.78 \\
$\mathbf{4 1 - 5 0}$ & 6 & 6.59 \\
$\mathbf{5 1 - 6 0}$ & 6 & 6.59 \\
$\mathbf{6 1 - 7 0}$ & 3 & 3.29 \\
$\mathbf{7 1 - 8 0}$ & 2 & 2.19 \\
$\mathbf{8 1 - 9 0}$ & 1 & 1.09 \\
\hline
\end{tabular}

Table 3: Distribution of color vision defects according to ethnic group $(n=971)$

\begin{tabular}{lccc}
\hline \multicolumn{1}{c}{ Ethnic group } & $\begin{array}{c}\text { Total } \\
\text { number }\end{array}$ & $\begin{array}{c}\text { Number } \\
\text { affected }\end{array}$ & Percentage \\
\hline Brahmin & 364 & 37 & 10.16 \\
Chhettri & 139 & 20 & 14.38 \\
Gurung & 132 & 7 & 5.30 \\
Magar & 91 & 9 & 9.89 \\
Newar & 106 & 7 & 6.60 \\
Others & 139 & 11 & 7.91 \\
\hline
\end{tabular}

Of the 971 patients, $91(9.37 \%)$ patients were found to have some kind of color vision defects. Among 91 patients, 69 patients $(75.82 \%)$ had congenital color vision defect whereas 22 patients $(24.18 \%)$ had acquired color vision defect. In congenital color vision defects $19(27.53 \%)$ were found with total color vision defects and $50(72.46 \%)$ had red- green 
defect (R-G defect) whereas in acquired color vision defects, $17(77.27 \%)$ were found with total color vision defects and $5(22.72 \%)$ with R-G defects (Table 4$)$.

Table 4: Distribution of various types of color vision defects $(\mathrm{n}=91)$

\begin{tabular}{lcc}
\hline \multicolumn{1}{c}{ Type } & Number & Percentage \\
\hline Congenital & 69 & 75.82 \\
Total color vision defect & 19 & 27.53 \\
Red- Green defect & 50 & 72.46 \\
Strong deutan & 38 & 76 \\
Mild deutan & 0 & 0 \\
Mild protan & 0 & 0 \\
Strong Protan & 12 & 24 \\
Acquired & 22 & 24.18 \\
Total color vision defect & 17 & 77.27 \\
Red- Green defect & 5 & 22.72 \\
Strong deutan & 4 & 80 \\
Mild deutan & 0 & 0 \\
Mild protan & 0 & 0 \\
Strong protan & 1 & 20 \\
\hline
\end{tabular}

In this study, acquired causes for color vision defects were papillitis, optic atrophy, immature senile nuclear cataract, traumatic optic neuropathy, stagardts diseases and meningioma.

\section{Discussion:}

Color vision defect is one of the common genetic disorders observed in human population. Being genetic disorder, the incidence of color vision defect vary from race to race and are, therefore, different in the different geographical regions of the world inhabited by people of different ethnicity. Color vision defects can also be observed in various optic nerve and retinal diseases.

Out of total 91 colors vision defect patients, 68 males $(74.72 \%)$ and 23 females $(25.27 \%)$ had color vision defects. In this study,congenital color vision defect was seen in $10.97 \%$ of males and $2.97 \%$ of females whereas acquired color vision defect was noted in $2.57 \%$ of males and $1.91 \%$ of females respectively (Table 1). Other studies also observed high incidence of color vision defect among males in country like Jordan $8.7 \%,{ }^{28} \quad$ Europe $8.0 \%,{ }^{11}$ America $8.0 \%,{ }^{12}$ and Iran $8.2 \% \cdot{ }^{13}$ However color vision defects was reported of lower incidence in Nepal $3.9 \%{ }^{14}$, India $2.3 \%,{ }^{15}$ and China $3.0 \%{ }^{16}$

As in our study,color vision defects in females were also noted in India $\left(0.1 \%\right.$ in Patiala city, ${ }^{17} 1.1 \%$ in Punjab $\left.{ }^{18}\right)$,
$0.4 \%$ in Korea ${ }^{19}$ and $0.4 \%$ in Tehran. ${ }^{13}$ However other studies done in Nepal, ${ }^{14}$ India, ${ }^{20}$ Tibet, ${ }^{21}$ Spain ${ }^{22}$ and Kenya ${ }^{23}$ didn't notice color vision defects in female.

Majority of the color vision defect is seen in males than in females. The incidence of male being affected is explained by the $\mathrm{x}$-linked genetic inheritance pattern, in which males are affected and females are carrier. The inheritance pattern of $y$ - linked and confused pattern in some cases have been reported, this possibly explains the number of female population affected. ${ }^{24}$

In this study, majority of the patients of color vision defects were in the second $(31.86 \%)$ and third $(23.07 \%)$ decade of life (Table 2). No other studies had mentioned the relationship of age with color vision defects. As color vision defect is a genetic problem, its incidence doesn't have relationship with age. We noticed that majority of patients were unaware about color vision defect so they were diagnosed only in adult life.

In our study color vision defects was observed more in Chhetri $14.38 \%$ followed by Brahmin 10.16\% and Magar caste $9.89 \%$ (Table 3 ) whereas in a study conducted in the same city in $\mathrm{Nepal}^{14}$ reported more color vision defects in Darji $14.3 \%$ followed by Newar $9.1 \%$. Since the color vision defect is genetically transmitted its distribution is likely to be variable in different ethnic groups.

Regarding various types of color vision defects in this study, more deutans were noted than protans(Table 4) which is comparable to other studies. ${ }^{25-27}$ This can be explained by the heredity of color vision defects. ${ }^{29}$

The acquired causes for color vision defects observed in this study were papillitis, optic atrophy followed by immature senile nuclear cataract, traumatic optic neuropathy and macular edema. In a study conducted in other part of Nepal,they didn't find obvious acquired cause for color vision defects. ${ }^{25}$ As other study was conducted only in school going children whereas we had included hospital patients.

\section{Conclusion:}

A significant number of the population suffers from color vision defects. Those with congenital color vision defects should be properly counseled so that they will be prepared for future challenge and possible confusion, especially in relation to their education and career choice.

\section{Conflict of interest: none}

Funding: none

\section{References:}

1. Emery AE. John Dalton (1766-1844). J Med Genet 1988;25: 422-6.

\section{http://dx.doi.org/10.1136/jmg.25.6.422}

2. Abc H, Sakai T, Yamazaki T. Selective impairment of the three - color mechanisms isolated bua new color campimeter. ActaSocOphthalmolJpn 1982;87:950-7. 
3. Zrenner E. Neurophysiological aspects of color vision mechanisms in the primate retina. In: Mollen JD, Sharpe LT, editors. Color vision physiology and psychophysics. New York: Academic Press Inc: 1983.

4. Zrenner E, Gouras P. Retinal ganglion cells lose color opponency at high flicker rates. Invest OphthalmolVisSci1978;17:130-4.

5. Spalding JAB. Color vision deficiency in medical profession. Br J Gen Pract 1999;49:469-75.

6. Ruddock KH. Acquired deficiencies of human color vision. Bailliere's clinical neurology. London: BailliereTindall, 1993.

7. Lakowski R. Is deterioration of color discrimination with age due to lens or retinal changes? Die fabre 1962;11:69-86.

8. Nathans J, Piantanida T, Eddy RL, et al. Molecular genetics of inherited variations in human color vision. Science 1986;232:203-32.

http://dx.doi.org/10.1126/science. 3485310

9. Taylor WOG. Effects on employment of defective color vision. Br J Ophthalmol 1971;79:447-52.

10. Holroyd E, Hall DMB. A re-appraisal of screening for color vision impairments in Edingburgh. Child Care Health Dev1997;23:391-8.

http://dx.doi.org/10.1111/j.1365-2214.1997.tb00906.x

11. Clements F. Racial difference in color blindness. Amer J PhysAnthrop 1961;4:189-204.

12. Mueller RF, Young ID. Emery's Elements of Medical Genetics. $9^{\text {th }}$ edition. Churchill Livingstone: Edinburgh 1995: 317.

13. Modarres M, Mirsamadi M, Peyman GA. Prevalence of Congenital color deficiencies in secondary school students in Tehran. Inter Ophthalmol 1997;20:221-2.

http://dx.doi.org/10.1007/BF00175263

14. Niroula DR, Saha CG. The incidence of color blindness among some school children of Pokhara, Western Nepal. Nepal Med Coll J 2010;12:48-50.

15. Rahman SA, Singh PN, Nanda PK. Comparison of the incidence of color blindness between sections of Labyan and Indian populations. Indian J PhysiolPharmacol 1998;42:271-5.

16. Huang $\mathrm{S}, \mathrm{Wu} \mathrm{L}, \mathrm{Wu} \mathrm{D}$. The proportion of various types of congenital color vision defects. Yan keXueBao 1990;6:40-2.

17. Naresh S. Study of color blindness in Jat Sikhs. Indian J PhysiolPharmacol 1995;39:127-30.

18. Bansal IJS. The frequency of color blindness among the Punjabis of India. J Genet Hum 1967;16:1-5.

19. Kim HB, Lee SY, Choe JK, et al. The incidence of congenital deficiency among Koreans Med Sci 1989;4:117-20.

20. Dutta PC, Kumar CD. The incidence of inherited defects of color vision in MP. Acta Genet Gen 1966;15:364-9.

21. Tiwari SC. The incidence of color blindness in Newars of Nepal valley. Acta Genet Basel 196;7:95-9.

22. Cabrera FJ, Ortiz MA, Mesa MS, et al. Red- green color blindness in the Tormer - Alberche valley (AvilaCentral Spain). AnthropolAnz 1997;55:295-301.

23. Oppolzer A, Winkler EM. Incidence of color blindness in East African Negroes. AnthropolAnz 1980;38:11720.

24. Emery AEH. Elements of Medical Genetics. $6^{\text {th }}$ edition. Churchill Livingstone: Edinburg;1983.

25. Shrestha RK, Joshi MR, Shakya S, et al. Color vision defects in school Going Children. J Nepal Med Assoc 2010;49:264-6.

26. Zein ZA. Gene frequency and type of color blindness in Ethiopeans. Ethiop Med J 1990;28:73-5.

27. Kaur N, Kumar A, Kaur G, et al. Study of color blindness in Tibetan population. Delhi Journal of Ophthalmology $2011 ; 21: 45-7$

28. Al-Aqtum MT, Al- Qawasmeh MH: Prevalence of Color - blindness in young Jordanians. Ophthalmologica 2001;215:39-42.

\section{http://dx.doi.org/10.1159/000050824}

29. Ganong WF. Vision. Review of Medical Physiology 2003;21:186. 